\title{
Alder pollen season in selected cities of Poland in 2020
}

\author{
Małgorzata Malkiewicz', Krystyna Piotrowska-Weryszko², Małgorzata Puc ${ }^{3}$, Anna Rapiejko, 5 , \\ Dariusz Jurkiewicz ${ }^{6}$, Grzegorz Siergiejk0 ${ }^{7}$, Katarzyna Dąbrowska-Zapart ${ }^{8}$, Ewa Kalinowska ${ }^{9}$, Agnieszka Lipiec ${ }^{10}$ \\ ${ }^{1}$ Laboratory of Paleobotany, Department of Stratigraphical Geology, Institute of Geological Sciences,
}

University of Wroclaw, Poland

${ }^{2}$ Department of Botany and Plant Physiology, University of Life Sciences in Lublin, Poland ${ }^{3}$ Institute of Marine \& Environmental Sciences, University of Szczecin, Poland ${ }^{4}$ Allergen Research Center, Warsaw, Poland

${ }^{5}$ Medical University of Warsaw, Poland

${ }^{6}$ Department of Otolaryngology with Division of Cranio-Maxillo-Facial Surgery in Military Institute of Medicine,

Warsaw, Poland

${ }^{7}$ Pediatrics, Gastroenterology and Allergology Department, University Children Hospital, Medical University of Bialystok, Poland ${ }^{8}$ Faculty of Natural Sciences, Institute of Earth Sciences, University of Silesia in Katowice, Poland

${ }^{9}$ Allergen Research Center, Warsaw, Poland

${ }^{10}$ Department of Prevention of Environmental Hazards and Allergology, Medical University of Warsaw, Poland

\begin{abstract}
:
This paper presents the course of alder pollination season in Poland in 2020. The measurements were performed in Bydgoszcz, Bialystok, Lublin, Olsztyn, Opole, Piotrkow Trybunalski, Sosnowiec, Szczecin, Warsaw, Wroclaw and Zielona Gora. Volumetric method with the use of Volumetric Spore Trap (Burkard, Lanzoni) was implemented. Pollen season was defined as the period in which $95 \%$ of the annual total catch occurred. The alder pollen season in 2020 started about 10-30 days earlier compared to 2017-2019. The pollen season started first in Szczecin, Opole and Zielona Gora (in the second half of January). In the other cities alder pollen season started in first half of February. The highest daily pollen count was recorded in Lublin $\left(1211 \mathrm{P} / \mathrm{m}^{3}\right.$ ). In other cities the maximum concentrations ranged from $160 \mathrm{P} / \mathrm{m}^{3}$ in Sosnowiec to $465 \mathrm{P} / \mathrm{m}^{3}$ in Piotrkow Trybunalski. The highest alder pollen concentrations were detected in the first decade of March (March $1^{\text {st }}-3^{\text {rd }}$ ). Only in Zielona Gora, Wroclaw, Opole and Sosnowiec the maximum concentration was recorded in the third decade of February. The annual pollen sum of Alnus in 2020 was even 5-10 times lower than in years 2019.
\end{abstract}

Key words: allergens, pollen count, alder (Alnus), 2020

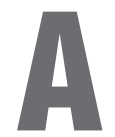

lder, birch and hazel are important sources of allergenic pollen in the temperate climatic zone of the Northern Hemisphere [1,5]. Also sensitization rates to trees belonging to the family Betulaceae (hazel, alder, birch) are high in Central/Western Europe, and Poland especially showing high sensitiza- tion rates for alder (22.8\%) [2]. The threshold value for clinical symptoms for Alnus pollen grains for the majority of patients is visible during exposure to the concentration of 45 pollen grains in $1 \mathrm{~m}^{3}$ of air. Symptoms were noted in all sensitized patients at the concentration of 85 grains $/ \mathrm{m}^{3}$ of air $[3,4]$. 
Aim

The aim of the study was to compare the alder pollen concentration in the air of in selected cities in Poland: Bydgoszcz, Bialystok, Lublin, Olsztyn, Opole, Piotrkow Trybunalski, Sosnowiec, Szczecin, Warsaw, Wroclaw and Zielona Gora in 2020.

\section{Material and method}

In 2020, the measurements of the pollen concentration in the study sites were performer with the volumetric method using Burkard and Lanzoni pollen samplers. Microscopic observations were performed on preparations obtained in a 7-day cycle with assessment of 24-hour periods. The length of the alder pollen seasons was determined with the $95 \%$ method. Pollen concentrations were expressed as the number of pollen grains in $1 \mathrm{~m}^{3}$ of air per day $\left(\mathrm{P} / \mathrm{m}^{3}\right)$. The course of the pollen seasons in each city is shown in the graphs (fig. 1-6).

\section{Results and discussion}

The onset of alder flowering period highly depends on atmospheric conditions, especially on cu- mulative air temperature. Depending on weather conditions, the duration of the alder pollen season can vary by $30-50$ days in individual years.

In 2020, the first grains of alder pollen were recorded in Lublin and Opole in the first decade of January. The alder pollen season (determined using the 95\% method), in three cities started in the second half of January and in the other cities in February (tab. 1). The earliest the alder pollen season started in Szczecin, Opole and Zielona Gora - January $22^{\text {nd }}, 27^{\text {th }}$ and $28^{\text {th }}$. In Bydgoszcz and in Olsztyn - February $2^{\text {nd }}$ and $4^{\text {th }}$, and in Sosnowiec, Warsaw and Wroclaw - February $9^{\text {th }}$ and $10^{\text {th }}$. The latest onset of the alder pollen season was recorded in Lublin and Bialystok - February $17^{\text {th }}$. In the comparison to previous years $(2017,2019)$ in 2020 alder pollen season started 10-20 days earlier [6-8]. Although in 2018 alder pollen season stared even later - at the beginning of March [9].

The highest alder pollen concentrations were detected in the first decade of March (March $1^{\text {st }}-3^{\text {rd }}$ ) in a majority of the analysed cities. Although in Zielona Gora, Wroclaw, Opole and Sosnowiec the maximum concentration occurred on February $22^{\text {nd }}$ and $23^{\text {rd }}$. Only in Szczecin the highest alder pollen concentra-

Table 1. Characteristics of Alnus pollen season in 2020.

\begin{tabular}{|c|c|c|c|c|c|}
\hline Site & $\begin{array}{l}\text { Pollen season period } \\
\text { by the } 95 \% \text { method }\end{array}$ & $\begin{array}{l}\text { Maximum pollen count }\left(\mathrm{P} / \mathrm{m}^{3}\right) \\
\text { (date) }\end{array}$ & $\begin{array}{l}\text { Annual pollen } \\
\text { sum }\end{array}$ & $\begin{array}{l}\text { Days number above threshold } \\
\qquad 45 \mathrm{P} / \mathrm{m}^{3}\end{array}$ & $\begin{array}{l}\text { Days number above threshold } \\
\qquad 85 \mathrm{P} / \mathrm{m}^{3}\end{array}$ \\
\hline Szczecin & $22.01-12.03$ & $\begin{array}{c}356 \\
16.02\end{array}$ & 1871 & 8 & 4 \\
\hline Bydgoszcz & $4.02-9.03$ & $\begin{array}{l}295 \\
1.03\end{array}$ & 2310 & 14 & 8 \\
\hline Olsztyn & $2.02-15.03$ & $\begin{array}{l}167 \\
3.03\end{array}$ & 1017 & 5 & 2 \\
\hline Bialystok & $17.02-14.03$ & $\begin{array}{l}314 \\
3.03\end{array}$ & 958 & 5 & 2 \\
\hline $\begin{array}{l}\text { Zielona } \\
\text { Gora }\end{array}$ & $28.01-7.03$ & $\begin{array}{c}376 \\
22.02\end{array}$ & 2884 & 18 & 12 \\
\hline Warsaw & $9.02-14.03$ & $\begin{array}{l}342 \\
3.03\end{array}$ & 2756 & 16 & 10 \\
\hline $\begin{array}{l}\text { Piotrkow } \\
\text { Trybunalski }\end{array}$ & $11.02-14.03$ & $\begin{array}{l}465 \\
3.03\end{array}$ & 3244 & 18 & 12 \\
\hline Lublin & $17.02-16.03$ & $\begin{array}{l}1211 \\
3.03\end{array}$ & 5096 & 23 & 16 \\
\hline Wroclaw & $9.02-16.03$ & $\begin{array}{c}263 \\
22.02\end{array}$ & 1826 & 10 & 4 \\
\hline Opole & 27.01-9.03 & $\begin{array}{c}290 \\
22.02\end{array}$ & 3037 & 19 & 10 \\
\hline Sosnowiec & $10.02-19.03$ & $\begin{array}{c}160 \\
23.02\end{array}$ & 1920 & 13 & 11 \\
\hline
\end{tabular}


Figure 1. Alder pollen count in Szczecin and Bydgoszcz in 2020.

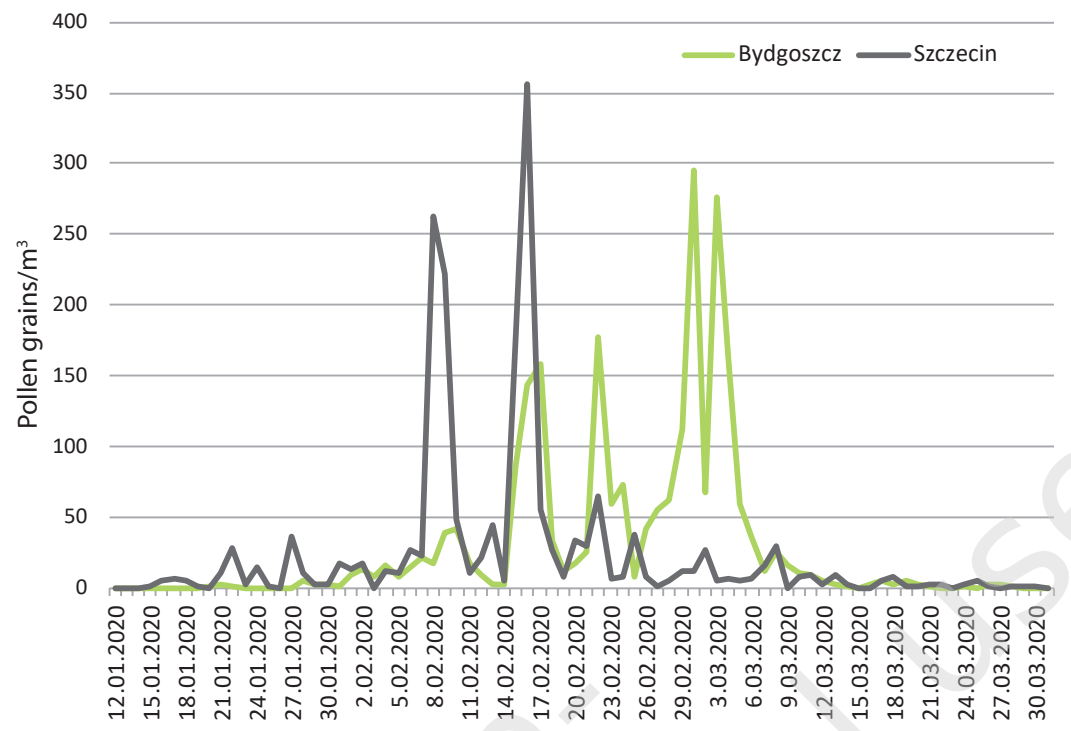

Figure 2. Alder pollen count in Bialystok and Olsztyn in 2020.

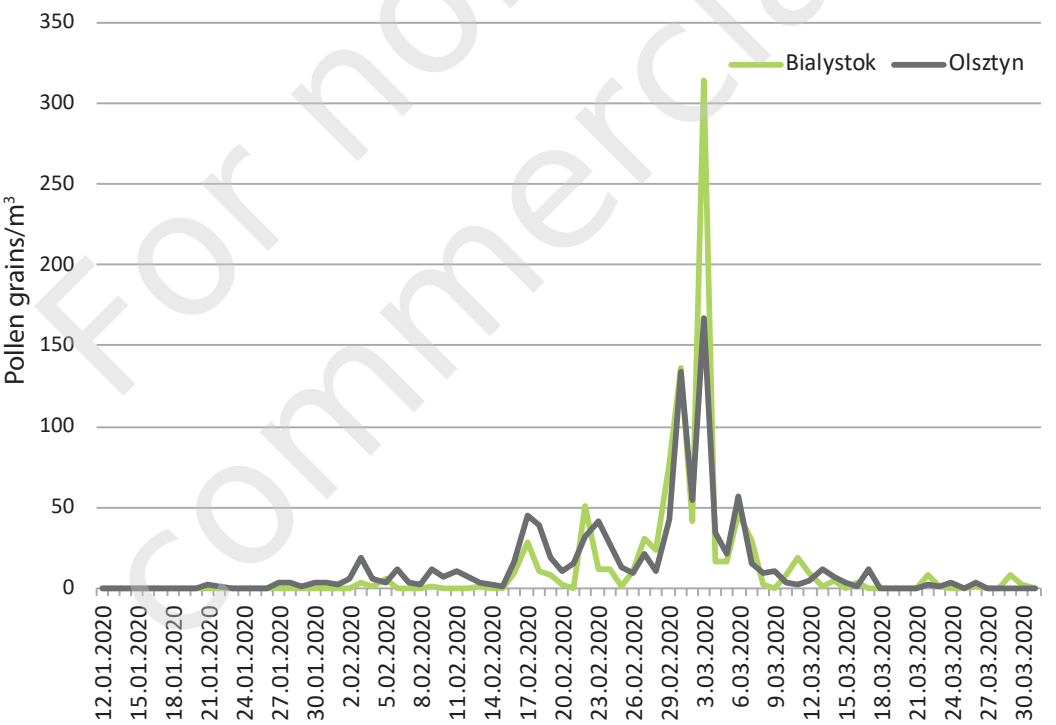

Figure 3. Alder pollen count in Piotrkow Trybunalski and Warsaw in 2020.

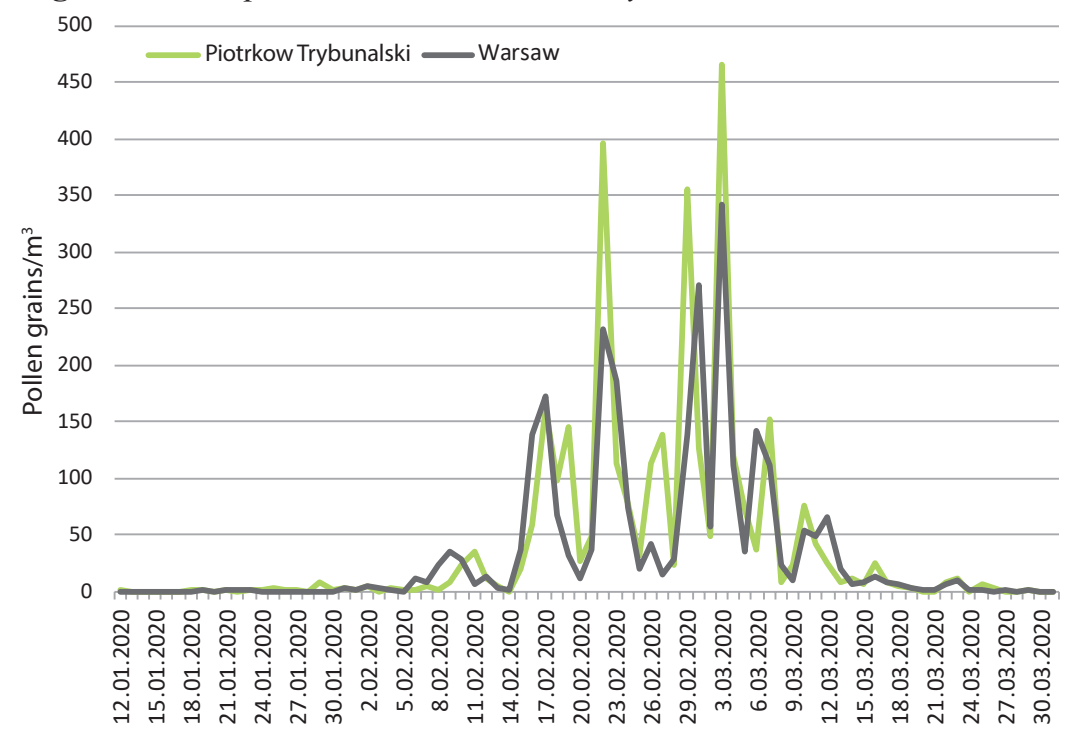


Figure 4. Alder pollen count in Zielona Gora and Wroclaw in 2020.

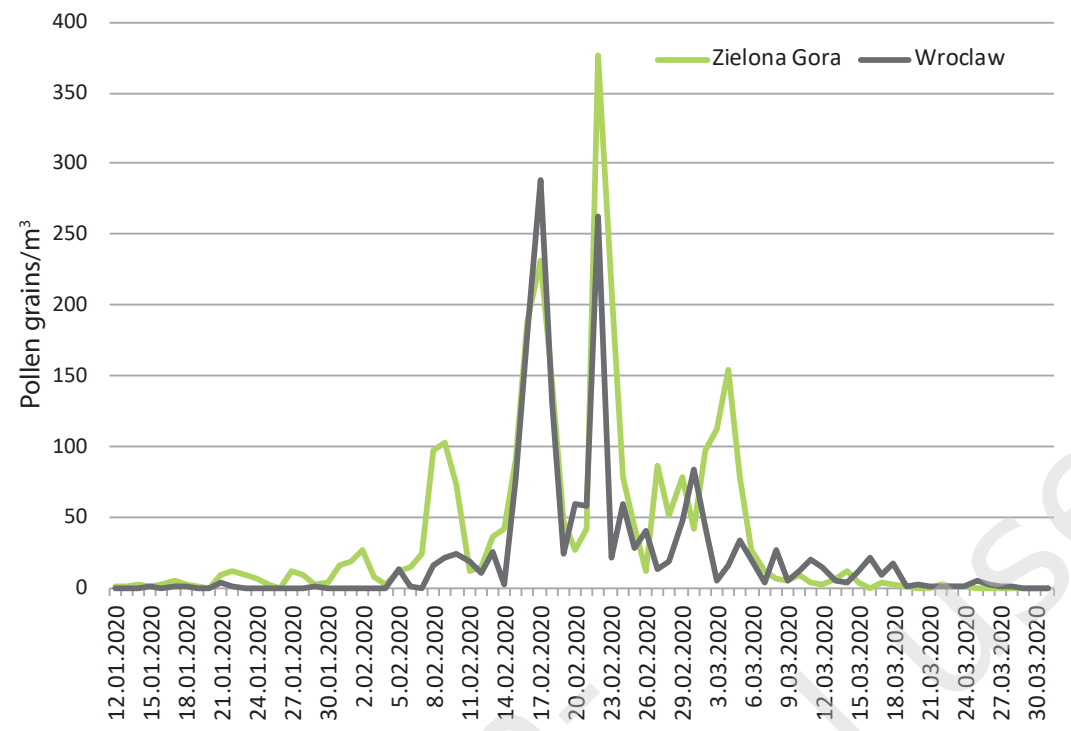

Figure 5. Alder pollen count in Sosnowiec and Opole in 2020.

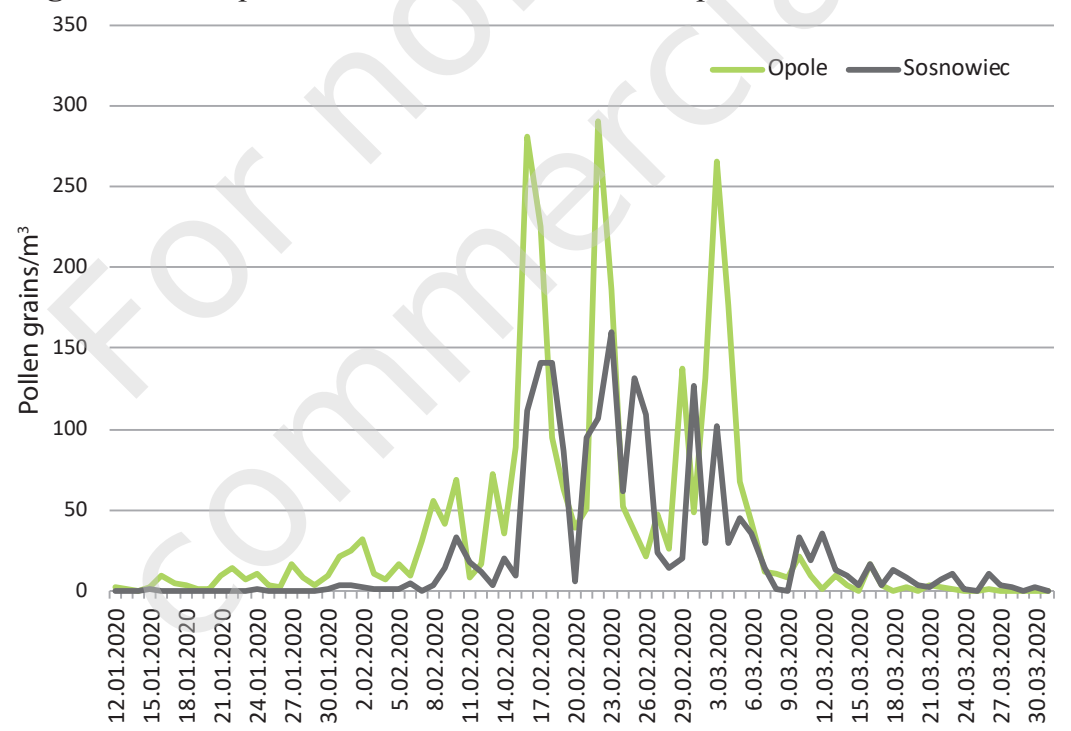

Figure 6. Alder pollen count in Lublin in 2020.

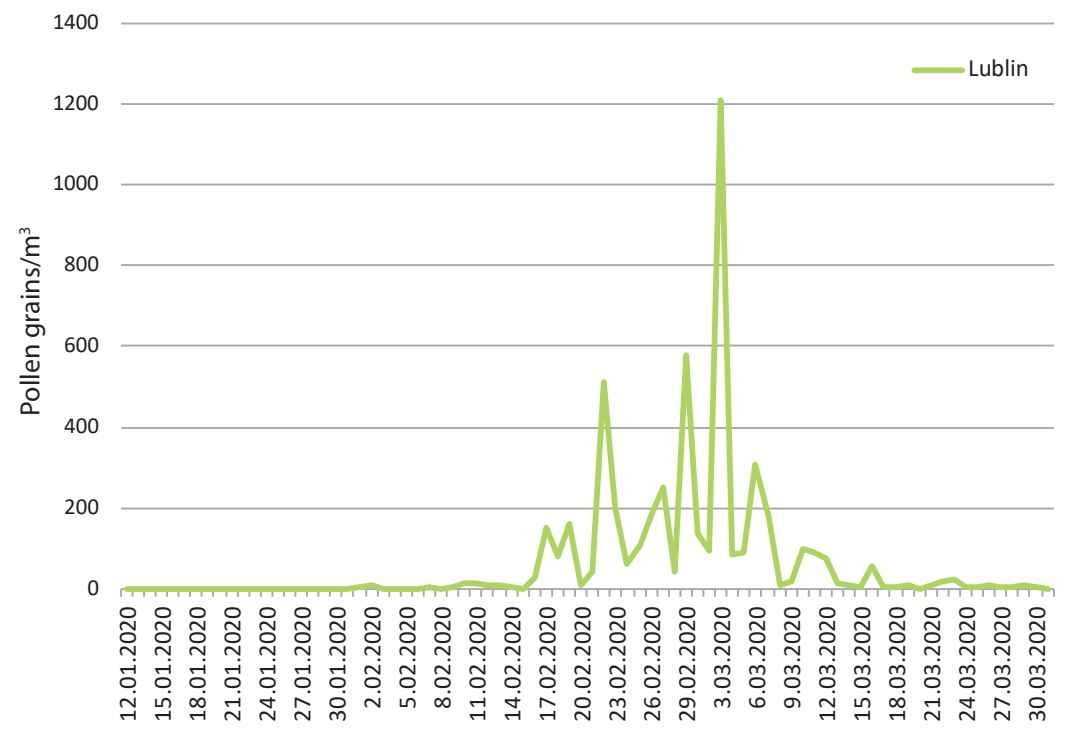


tion occured almost 16 days earlier (February $16^{\text {th }}$ ). The highest daily pollen count was recorded in Lublin - $1211 \mathrm{P} / \mathrm{m}^{3}$ (fig. 6). In other cities the maximum concentrations ranged from $263 \mathrm{P} / \mathrm{m}^{3}$ in Wroclaw to 465 $\mathrm{P} / \mathrm{m}^{3}$ in Piotrkow Trybunalski (fig. 3, 4). The lowest daily alder pollen concentration were noted in Sosnowiec $-160 \mathrm{P} / \mathrm{m}^{3}$ and Olsztyn $-167 \mathrm{P} / \mathrm{m}^{3}$ (fig. 2, 5). The highest alder pollen concentrations were few times higher than in 2019 [6].

The highest annual pollen sum of alder pollen grains were recorded in Lublin - 5096 pollen grains. They were similarly high in Opole and Piotrkow Trybunalski. In other cities annual pollen sum of alder pollen grains ranged between 1017 in Olsztyn to 2884 in Zielona Gora. Only in Bialystok the annual pollen sum of alder pollen grains hasn't exceed 1000 (tab. 1). The annual pollen sum of Alnus in 2020 was even 5-10 times lower than in years 2019 [6].

The comparison with alder pollen seasons in previous years revealed that in 2020 alder pollen concentrations in all cities were much lower than in 2019 [6]. The highest risk of pollen allergy expressed in days with pollen levels exceeding the threshold value at which first symptoms of allergy develop $\left(45 \mathrm{P} / \mathrm{m}^{3}\right)$ was shown for Lublin (23 days) and for Opole, Piotrkow Trybunalski and Zielona Gora (18, 19 days). In the other analysed cities, the risk of allergies related to the pollen levels exceeding the threshold value persisted from 5 to 16 days. Pollen concentration causing severe clinical symptoms (above $85 \mathrm{P} / \mathrm{m}^{3}$ ) was detected in Lublin (16 days) and in Piotrkow Trybunalski and Zielona Gora (12 days). Only one day with the concentration above $1200 \mathrm{P} / \mathrm{m}^{3}$ was recorded in Lublin.

\section{Conclusions}

1. In 2020, the alder pollen season began in the second half of January and first half of February.

2. The maximum concentrations of alder pollen were recorded on second half of February and first days of March.

3. The highest concentrations for alder pollen were noted in Lublin, whereas the lowest concentrations were recorded for Sosnowiec.

4. The annual pollen sums in 2020 were much lower than those in the previous year.

5. The greatest number of days with concentrations exceeding the threshold value was noted in Lublin, Opole, Piotrkow Trybunalski and Zielona Gora.

\section{References}

1. Rodriguez-Rajo FJ, Dopazo A, Jato V. Environmental factors affecting the start of pollen season and concentrations of airborne Alnus pollen in two localities of Galicia (NW Spain). Ann Agric Environ Med. 2004; 11(1): 35-44.

2. Heinzerling LM, Burbach GJ, Edenharter G et al. GA(2)LEN skin test study I: GA(2)LEN harmonization of skin prick testing: Novel sensitization patterns for inhalant allergens in Europe. Allergy. 2009; 64(10): 1498-506.

3. Rapiejko P, Lipiec A, Wojdas A et al. Threshold pollen concentration necessary to evoke allergic symptoms. Int Rev Allergol Clin. 2004; 10(3): 91-4.

4. Rapiejko P. Alergeny pytku roślin. Medical Education, Warszawa 2008.

5. González-Parrado Z, Fuertes-Rodriguez CR, Vega-Maray AM et al. Chilling and heat requirements for the prediction of the beginning of the pollen season of Alnus glutinosa (L.) Gaertner in Ponferrada (León, Spain). Aerobiologia. 2006; 22(1): 47-53.

6. Malkiewicz M, Puc M, Stacewicz A et al. Alder pollen season in selected cities of Poland in 2019. Alergoprofil. 2019; 15(1): 22-6.

7. Piotrowska-Weryszko K, Rapiejko P, Weryszko-Chmielewska E et al. Alnus pollen season in selected cities of Poland in 2017. Alergoprofil. 2017; 13(2): 81-4.

8. Puc M, Lipiec A, Kotrych $D$ et al. Alder pollen season in northern Poland in 2017. Alergoprofil. 2017; 13(2): 77-80

9. Rapiejko P, Puc M, Malkiewicz M et al. Alnus pollen season in Poland in 2018. Alergoprofil. 2018; 14(1): 27-31.

ORCID

M. Malkiewicz - ID - http://orcid.org/0000-0001-6768-7968

K. Piotrowska-Weryszko - ID - http://orcid.org/0000-0003-3827-3218

M. Puc - ID - http://orcid.org/0000-0001-6734-9352

A. Rapiejko - ID - http://orcid.org/0000-0002-8906-2405

D. Jurkiewicz - ID - http:///orcid.org/0000-0003-3729-2679

G. Siergiejko - ID - http://orcid.org/0000-0003-4084-8332

K. Dąbrowska-Zapart - ID - http://orcid.org/0000-0002-8976-7739

E. Kalinowska - ID - http:///orcid.org/0000-0003-4821-6882

A. Lipiec - ID - http://orcid. org/0000-0003-3037-2326

Author's contributions: Malkiewicz M.: 60\%, and other authors: $5 \%$ each. Conflict of interests: The authors declare that they have no competing interests. Ethics: The contents presented in this paper are compatible with the rules the Declaration of Helsinki, EU directives and standardized requirements for medical journals.

Financial support: Research in Bialystok, Bydgoszcz, Olsztyn, Opole, Warsaw, Zielona Gora and Piotrkow Trybunalski funded by Allergen Research Center Ltd. (Ośrodek Badania Alergenów Środowiskowych Sp. z 0.0.).

Copyright: (C) Medical Education sp. z 0.0. This is an Open Access article distributed under the terms of the Attribution-NonCommercial 4.0 International (CC BY-NC 4.0). License (https://creativecommons.org/licenses/by-nc/4.0/), allowing third parties to copy and redistribute the material in any medium or format and to remix, transform, and build upon the material, provided the original work is properly cited and states its license. 
Corresponding author:

\section{Małgorzata Malkiewicz, PhD}

Laboratory of Paleobotany,

Department of Stratigraphical Geology,

Institute of Geological Sciences,

University of Wroclaw

50-205 Wroclaw, Cybulskiego 34

e-mail: malgorzata.malkiewicz@uwr.edu.pl

(c) Medical Education. For private and non-commercial use only. Downloaded from https://www.journalsmededu.pl/index.php/alergoprofil: 26.04.2023; 09:26,15 